\title{
IDENTIFIKASI POTENSI OBJEK DAYA TARIK WISATA ALAM DI HULU DAS BENGKULU DESA RINDU HATI KECAMATAN TABA PENANJUNG BENGKULU TENGAH
}

\author{
Mohammad Nur Dita Nugroho ${ }^{1 *}$, Siswahyono ${ }^{2)}$, Ari Anggoro ${ }^{3)}$ Supadi ${ }^{4)}$, Eko Sumartono ${ }^{5)}$ \\ *) Corresponding author email : $\underline{\text { mnd.nugroho@ unib.ac.id }}$ \\ 1) Program Studi Arsitektur, Fakultas Teknik, Universitas Bengkulu \\ 2) Program Studi Kehutanan, Fakultas Pertanian, Universitas Bengkulu \\ 3) Program Studi Kelautan, Fakultas Pertanian, Universitas Bengkulu \\ 4) Program Studi Pendidikan Bahasa \& Sastra Indonesia, FKIP, Universitas Bengkulu \\ 5) Program Studi Agribisnis, Sosial Ekonomi Pertanian, Universitas Dehasen Bengkulu
}

Article info

MODUL vol 2x no y, issues period 202x

Doi : :10.14710/mdl.21.1.2021.51-62

Received : 22 desember 2020

Revised : 25 mei 2021

Accepted : 27 mei 2021

\begin{abstract}
Daerah Aliran Sungai (DAS) Bengkulu merupakan suatu bentuk bentang alam yang memiliki peran penting bagi masyarakat di Kota Bengkulu dan Kabupaten Bengkulu Tengah. Salah satu hulu DAS Bengkulu berada di Sub-DAS Rindu Hati yang berada di Desa Rindu Hati Kecamatan Taba Penanjung, Kabupaten Bengkulu Tengah yang memiliki bentang alam yang masih alami dan asri. Tawaran pengembangan wisata berbasis alam di Desa Rindu Hati dengan ekowisata sebagai salah satu kegiatan konservasi yang dapat menjadi usaha berkelanjutan dan bernilai secara ekonomi bagi masyarakat yang tinggal di dalam dan di sekitar kawasan konservasi. Identifikasi potensi daya tarik wisata yang dilakukan bertujuan untuk memahami dan mendeskripsikan keberadaan berbagai jenis potensi lingkungan alam dengan segala karakteristiknya untuk dijadikan sebagai daya tarik wisata. Metode yang digunakan dalam studi identifikasi ini ialah deskriptif berdasarkan Pedoman Analisis Daerah Operasi Obyek dan Daya Tarik Wisata alam (ADO ODTWA) Dirjen PHKA tahun 2003 yang telah dimodifikasi. Data yang disajikan dalam bentuk deskripsi tentang jenis dan karakteristik potensi daya tarik wisata alam yang diperoleh melalui pengamatan lapangan, kuesioner, studi pustaka, dan instrumen penilaian. Hasil penelitian ini menunjukkan nilai sedang, cukup potensial. Sebagai langkah awal, Desa Rindu Hati memiliki potensi yang cukup besar untuk dikembangkan sebagai desa wisata berbasis alam.
\end{abstract}

Mohammad Nur Dita Nugroho, Siswahyono, Ari Anggoro, Supadi
Keywords: Daerah Aliran Sungai Bengkulu; Identifikasi Potensi Daya Tarik Wisata Alam; Ekowisata; Desa Rindu Hati;

\section{PENDAHULUAN}

Kerusakan DAS Bengkulu saat ini merupakan kerusakan sistemis dari hulu hingga hilir yang mengancam keberlanjutan lingkungan. Pemanfaatan sumber daya alam yang kurang memperhatikan kaidahkaidah kelestarian di wilayah DAS Bengkulu sebagai akibat dari pertambangan, pembangunan, pertambahan penduduk, perkembangan ekonomi, dan kurang sinerginya antar sektor, telah berkontribusi dalam kerusakan DAS Bengkulu. Saat terjadi kerusakan DAS di daerah hilir, tidak ada satu pun institusi yang mengurus dan bertanggung jawab dengan penuh untuk mengembalikan kelestarian dan keberlanjutan wilayah DAS dari hulu hingga hilir.

Salah satu Sub-DAS yang berada di hulu DAS Bengkulu ialah Sub-DAS Rindu Hati yang terletak di Desa Rindu Hati, Kecamatan Taba Penanjung, Kabupaten Bengkulu Tengah. Kondisi geografis desa yang bersebelahan dengan kawasan hutan Bukit Barisan memiliki bentang alam yang relatif asri dan alami dengan sawah dan pepohonan yang membentang sepanjang desa. Kondisi lingkungan yang masih alami dan terbatasnya pembangunan infrastruktur di desa membuat terbatasnya akses masyarakat dalam upaya melakukan pengawasan kondisi hulu DAS Bengkulu. Kondisi desa yang masih asri dan alami berpotensi untuk menggerakkan dan menggugah kesadaran masyarakat untuk terus melakukan kegiatan menjaga kelestarian (konservasi) lingkungan melalui kegiatan wisata.

Identifikasi potensi objek daya tarik wisata berbasis alam di Desa Rindu Hati perlu dilakukan pada 
tahap awal untuk membentuk Desa Rindu Hati menjadi desa wisata berbasis alam ke depannya. Potensi alam desa yang masih asri dan alami dapat menjadi wisata alam alternatif dengan celah pasar khusus (niche market) bagi wisatawan yang ingin menikmati suasana desa yang asri dengan objek wisata alam yang penuh tantangan.

\section{STUDI LITERATUR}

DAS merupakan ekosistem, di mana unsur organisme dan lingkungan biofisik serta unsur kimia berinteraksi secara dinamis dan di dalamnya terdapat keseimbangan inflow dan outflow dari material dan energi (Kurniasari et al. 2013). Ekosistem DAS dapat diklasifikasikan menjadi daerah hulu, tengah, dan hilir. Daerah hulu dicirikan sebagai ekosistem pedesaan dengan empat komponen utama, yaitu: desa, sawah/ladang, sungai, dan hutan (Soemarwoto, 1989).

Daya tarik wisata adalah segala sesuatu yang menjadi daya tarik bagi seseorang untuk mengunjungi daerah tertentu. Inskeep (1991) dalam Adiati \& Basalamah (2014) mengatakan bahwa komponenkomponen dalam pengembangan destinasi wisata terdiri dari tourist attraction and activities, accommodation, other tourist facilities and services, transportation facilities and services, other infrastructure, dan institutional element. Yoeti (2008) dalam Nugroho (2015) menyatakan bahwa terdapat tiga unsur penting pembentuk produk industri pariwisata, yaitu: a) tersedianya atraksi wisata, objek dan kegiatan yang ada sebagai daya tarik yang menyebabkan wisatawan mau berkunjung ke negara, kota, atau objek wisata tersebut, b) adanya amenitas/fasilitas wisata, semua bentuk fasilitas yang dapat memberikan pelayanan untuk segala kebutuhan bagi wisatawan selama tinggal atau berkunjung, dan c) tersedianya aksesibilitas, segala prasarana yang memberikan kemudahan bagi wisatawan untuk mengunjungi objek wisata. Selain tiga unsur di atas tersebut, terdapat satu unsur tambahan untuk melengkapi produk wisata yakni, ancillary services atau pelayanan tambahan yang merupakan seluruh sarana maupun prasarana publik yang dapat melayani kebutuhan lain wisatawan selama berwisata. Komponen pembentuk produk wisata yang terdiri dari: atraksi, akses, amenitas/ fasilitas wisata, dan pelayanan tambahan (Nugroho, 2015).

Pengembangan pariwisata berkaitan erat dengan sumberdaya alam yang tersedia, pada kenyataan merupakan satu kesatuan dari potensi kawasan obyek wisata (Rebong, et al. 2017). Potensi daya tarik wisata dapat diartikan sebagai segala sumberdaya alam, budaya, dan buatan manusia yang berpotensi untuk dikembangkan menjadi daya tarik wisata. Pengembangan ekowisata dengan pengelolaan bersama masyarakat sekitar dapat meningkatkan kesejahteraan dan peran serta masyarakat dalam melestarikan kawasan (Purnomo et al. 2013 dalam Iskandarrudin et al. 2018).
Secara garis besar jenis-jenis daya tarik wisata alam dapat dibedakan menjadi: i) daya tarik wisata alam yang berbasis potensi keanekaragaman dan keunikan lingkungan alam di wilayah perairan laut dan ii) daya tarik wisata alam yang berbasis potensi keanekaragaman dan keunikan bentang lingkungan alam di wilayah daratan. Daya tarik wisata alam yang berbasis potensi keanekaragaman dan keunikan lingkungan alam di wilayah daratan, antara lain: i) pegunungan dan hutan alam/ taman nasional/ taman wisata alam/ taman hutan raya, ii) perairan sungai dan danau, iii) perkebunan, iv) pertanian, dan v) bentang alam khusus. (Pujaastawa \& Ariana, 2015).

\section{METODE PENELITIAN}

Penelitian ini mengambil lokasi di Desa Rindu Hati, Kecamatan Taba Penanjung, Kabupaten Bengkulu Tengah. Desa dengan bentang alam yang masih asri dan alami yang berjarak 43 kilometer dari Kota Bengkulu. Desa Rindu Hati berbatasan dengan kawasan bukit barisan, Taman Nasional Bukit Daun dan berada di wilayah, tepatnya di Sub-DAS Rindu Hati yang menjadi bagian dari hulu DAS Bengkulu.

Metode pendekatan yang digunakan dalam studi ini lebih bersifat deskriptif untuk menjelaskan fenomena di lapangan. Data terkait jenis dan karakteristik potensi daya tarik wisata alam diperoleh melalui observasi (pengamatan langsung di lapangan), interview (wawancara), lembar penilaian (asestment), maupun studi pustaka.

Metode analisis data yang digunakan ialah Pedoman Analisis Daerah Operasi Obyek dan Daya Tarik Wisata alam (ADO ODTWA) Dirjen PHKA 2003 yang telah dimodifikasi. Penggunaan metode ini untuk mengetahui keadaan kawasan dan menentukan skala prioritas pengembangan dan alternatif perencanaan kawasan wisata (Susanti,2015; Susanti \& Mandaka, 2019 dan Susana et al. 2020). Adapun kriteria yang menjadi penilaian antara lain: 1 . Objek daya tarik wisata yang berbentuk darat, 2. Aksesibilitas, 3. Kondisi sekitar kawasan, 4. Daya dukung kawasan, 5. Pengelolaan dan pelayanan, 6. Akomodasi, 7. Sarana prasarana penunjang, 8. Ketersediaan air bersih, 9. Keamanan, 10. Potensi Pasar, 11. Pemasaran, dan 12. Pangsa Pasar.

\section{ANALISIS DAN PEMBAHASAN}

Studi identifikasi potensi daya tarik wisata alam (ODTWA) bertujuan untuk memahami dan menjelaskan keberadaan berbagai jenis potensi daya tarik wisata dengan segala karakteristik bentang lingkungan alam yang ada. Potensi tersebut diharapkan menjadi daya tarik wisata yang dapat memberikan kepuasan bagi wisatawan dalam melakukan kunjungan wisata. Identifikasi yang dilakukan disertai dengan Analisis Daerah Operasi - Obyek dan Daya Tarik Wisata Alam (ADO-ODTWA). Analisis ODTWA merupakan 
instrumen penilaian untuk pengembangan suatu objek dapat dikembangkan menjadi objek daya tarik wisata alam. Hasil rekapitulasi penilaian dari tiap parameter penilaian dalam ADO-ODTWA mengindikasikan parameter yang perlu ditingkatkan untuk mengembangkan suatu wilayah menjadi daya tarik wisata berbasis alam.

Sebelum dilakukan analisis ADO ODTWA, perlu dilakukan kajian kondisi eksisting desa. Hasil survei dan pengamatan lapangan dituangkan sebagai data awal untuk dilakukan analisis di tahap selanjutnya. Adapun kondisi permukiman desa Rindu Hati yang akan dijadikan desa wisata berbasis alam dapat dijelaskan sebagai berikut.

\section{Kondisi Desa Rindu Hati}

\section{Pola permukiman}

Pola permukiman yang terjadi ialah memanjang sejajar dengan aliran sungai dan sudah tertata rapi (dapat dilihat dari citra udara). Masyarakat menghindari pengembangan pembangunan yang dapat merusak lingkungan dan alih fungsi lahan (lihat gambar 1). Hal tersebut dapat dilihat dari arah pengembangan permukiman yang menyebar ke sisi utara desa yang merupakan daerah perbukitan bukan ke sisi selatan dan timur yang merupakan lahan persawahan.

Peta Tata Ruang Citra Foto Udara Desa Rindu Hati Tahun 2020

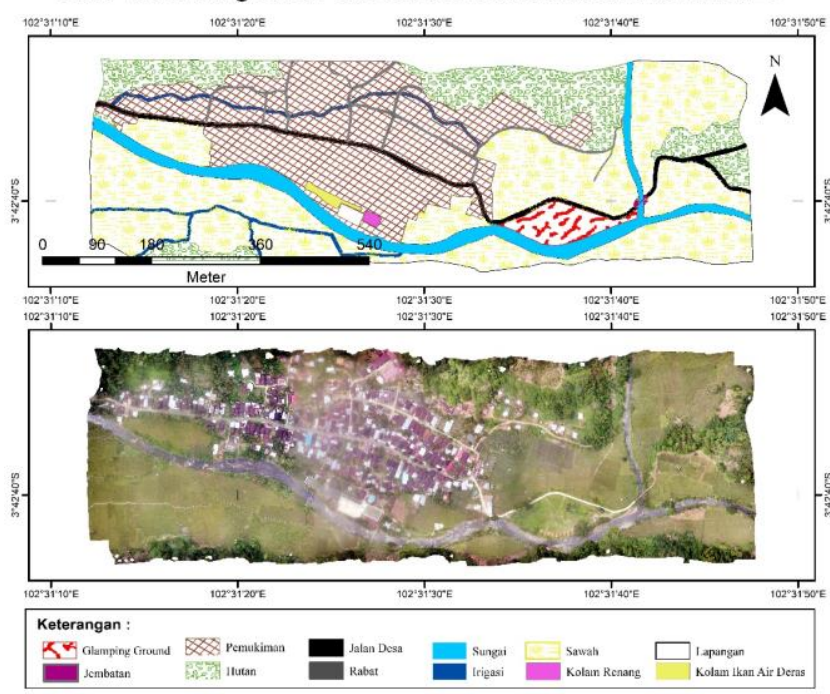

Gambar 1. Peta tata ruang dan citra udara Desa Rindu Hati (sumber: analisis citra udara oleh penyusun, 2020)

\section{Fasilitas desa}

Pengembangan fasilitas umum dan sosial yang terletak di desa tersebar di pinggir pemukiman. Terdapat masjid, sekolah dasar, puskesmas, pemakaman, lapangan, sarana olahraga, dan fasilitas lain yang menunjang kegiatan desa (lihat gambar 2). Fasilitas kepariwisataan yang sudah dirancang di lapangan desa ialah glamping ground aula, gudang, dan toilet umum.
Perlu penambahan fasilitas penunjang wisata untuk selain untuk meningkatkan kualitas kunjungan wisata juga mampu melayani wisatawan saat peak sesaon. Selain itu perlu adanya ikon untuk menjadi pintu masuk menuju atraksi wisata yang ada di desa. Sehingga wisatawan dapat membedakan kawasan permukiman desa dan kawasan yang diperuntukkan untuk kegiatan wisata.

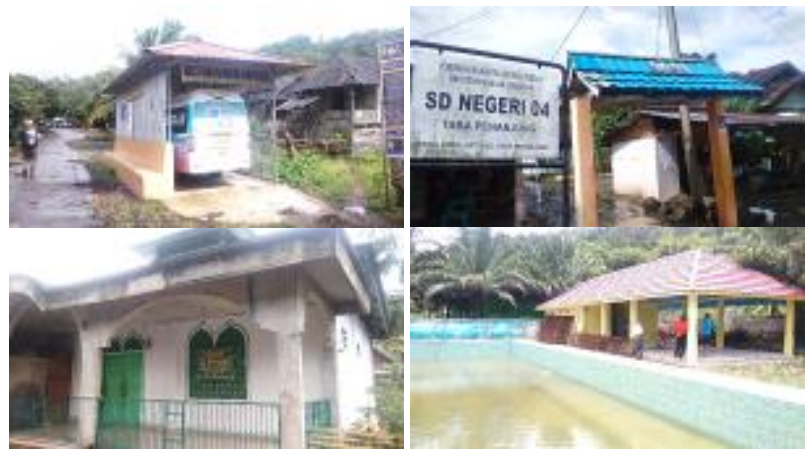

Gambar 2. Fasilitas di Desa Rindu Hati (sumber: survei penyusun, 2020)

\section{Aksesibilitas desa}

Aksesibilitas utama menuju desa cukup baik dengan jalan yang telah dilapisi aspal. Namun ada di beberapa titik yang membutuhkan perbaikan dan peningkatan kualitas material jalan. Untuk saat ini, jalan tersebut hanya dapat dilalui oleh kendaraan roda dua dan roda empat. Akses internal di dalam desa juga terus melakukan pembenahan. Peningkatan jalan dari jalan setapak menjadi jalan rabat beton di penjuru desa telah dilakukan. Lebar badan jalan 3 meter dirasa cukup untuk mobilisasi internal desa. (gambar 3)

Akses dari desa menuju titik wisata belum seutuhnya mendapatkan perhatian. Beberapa potensi atraksi wisata yang menarik, hanya dapat dilalui dengan berjalan kaki di jalan setapak. Keterbatasan akses ini memberi dampak bagi kegiatan wisata yakni pembatasan alami jumlah kunjungan yang ingin menuju objek wisata alam potensial di desa tersebut. Hanya wisatawan dengan motivasi tinggi yang akan melakukan petualangan menikmati keindahan desa.
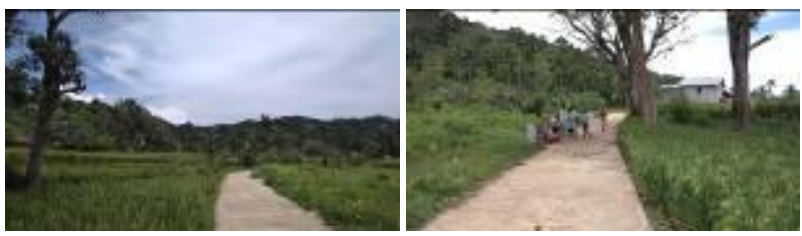

Gambar 3. Aksesibilitas internal Desa Rindu Hati (sumber: survei penyusun, 2020)

\section{Bentang alam}

Letak desa yang berada di 143 mdpl yang berada di sub-DAS Rindu Hati membuat topografi desa relatif datar yang diapit oleh bukit barisan. Sungai yang 
membelah desa dari timur ke barat mengakibatkan lahan desa baik untuk kegiatan agraris, selain menjadi daerah tangkapan air hujan (lihat gambar 4).

Kemiringan lereng yang cukup landai $<30^{\circ}$ dapat disiasati dengan kegiatan berkebun dan ladang untuk mengurangi terjadinya erosi. Perkebunan kopi dan durian yang menjadi komoditi primadona desa dilakukan dengan cara pemanfaatan hutan yang lestari.

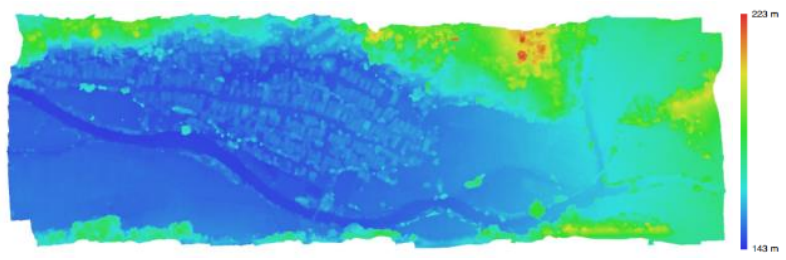

Gambar 4. Citra udara kontur Desa Rindu Hati (sumber: survei penyusun, 2020)

\section{Zonasi pariwisata desa wisata berbasis alam}

Zonasi yang dilakukan menggunakan parameter jarak/ radius, dengan desa sebagai pusat kegiatan wisata. Pengembangan wisata ke arah luar ruang permukiman merupakan cara untuk mengurangi kepadatan dalam tata ruang desa. Lokasi kegiatan/atraksi wisata yang semakin menjauh dari desa, mengakibatkan semakin berkurang kepadatan wisatawan dalam satuan luas. Sehingga daya dukung lingkungan akibat dari kegiatan wisata tidak terlampaui dan keasrian lingkungan tetap terjaga. Terlebih hal ini sangat menguntungkan untuk kegiatan wisata pasca pandemi corona. Adapun pembagian zonasi kegiatan pariwisata dapat dibagi menjadi 3 bagian zonasi (gambar 5).

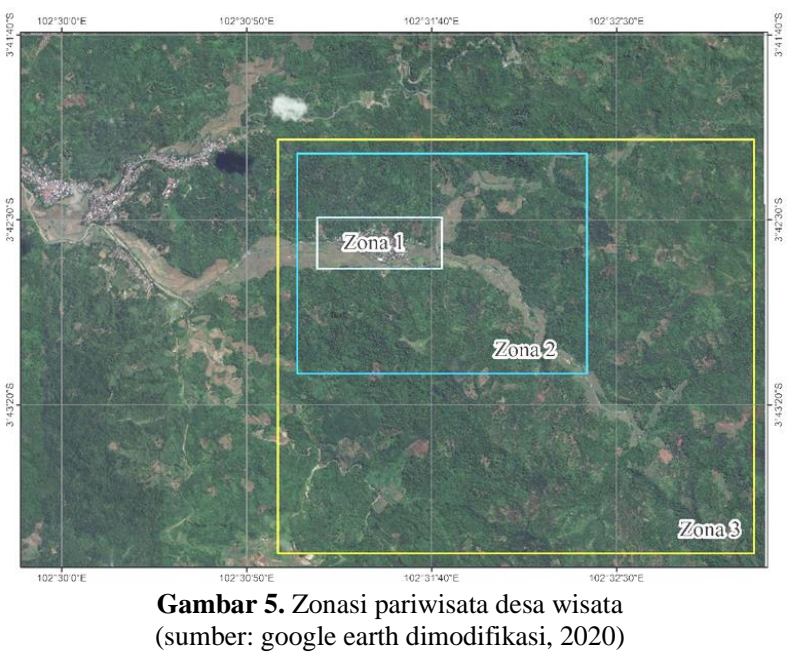

Zona I merupakan kawasan permukiman desa dengan segala aktivitasnya. Kegiatan wisata yang dapat dilakukan merupakan kegiatan wisata keluarga ataupun kegiatan rekreasi. Kegiatan yang minim risiko, tidak membutuhkan banyak energi untuk mencapai objek wisata/ atraksi, wisatawan dapat mudah menjangkau, dan ketersediaan sarana dan prasarana pariwisata yang beragam.

Zona II merupakan zona pemanfaatan. Zona II memiliki radius $1-2,5$ kilometer dari zona pertama. Kegiatan yang dilakukan membutuhkan energi lebih untuk mengeksplorasi atraksi maupun wahana yang ditawarkan oleh desa wisata. Wisatawan dapat menjangkau zona II tanpa menggunakan bantuan moda transportasi, kondisi akses berupa jalan setapak memberikan pengalaman dan tantangan bagi wisatawan. Pengembangan kegiatan wisata di Zona II lebih ke arah kegiatan yang mampu menarik wisatawan dan tetap menjaga keseimbangan lingkungan.

Zona III merupakan zona konservatif. Zona III memiliki radius 2,5 - 5 Kilometer dari desa merupakan zona penyangga hutan secara lestari untuk kegiatan wisata. Pemanfaatan zona konservatif berarti memanfaatkan ruang dengan sarana \& prasarana yang terbatas untuk mengurangi dampak dari kegiatan wisata yang telah dilakukan. Akses yang masih berupa jalan setapak, jalan pematang sawah, hingga melintasi air untuk kegiatan tracking merupakan tantangan yang tidak semua wisatawan mampu menikmatinya.

\section{Identifikasi Potensi Lingkungan Alam}

Identifikasi potensi lingkungan alam yang dilakukan merujuk pada jenis keunikan alam yang menjadi potensi daya tarik wisata. Keunikan alam yang menjadi potensi di Desa Rindu Hati selain sungai ialah, perkebunan, persawahan, hutan, air terjun, dan danau. Adapun pedoman yang digunakan mengidentifikasi sudah dilakukan modifikasi sesuai peruntukkan penelitian ini. Deskripsi mengenai potensi daya tarik wisata yang terdapat di Desa Rindu Hati dapat dilihat sebagai berikut:

\section{Sungai}

Sungai di Desa Rindu Hati merupakan Sub-DAS Rindu Hati yang terletak di hulu DAS Bengkulu. Sungai ini mengalir dari timur menuju barat di sisi selatan Desa Rindu Hati. Kondisi lingkungan sungai yang masih bersih dan alami dengan arus yang cukup deras dapat dimanfaatkan untuk kegiatan pertanian, rumah tangga, maupun wisata.

Sungai ini merupakan sub-DAS Rindu hati yang memiliki panjang $\pm 5 \mathrm{Km}$ dengan lebar $20-30$ meter. Sungai yang ini cukup dangkal dengan arus yang cukup deras yang merupakan karakteristik hulu sungai (lihat gambar 6). Akses menuju sungai cukup baik dengan 
jalan setapak yang mudah dijangkau dengan berjalan kaki maupun roda dua.

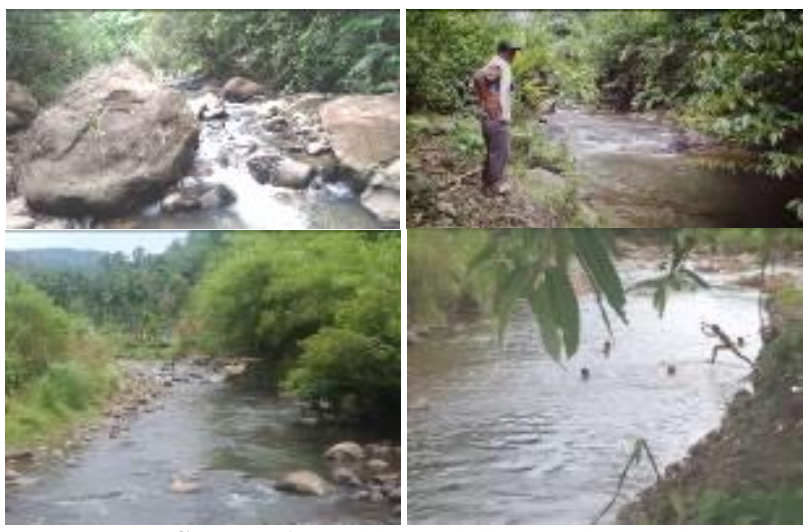

Gambar 6. kondisi sungai di Desa Rindu Hati (sumber: survei penyusun, 2020)

Berdasarkan identifikasi yang dilakukan, potensi sungai untuk dijadikan daya tarik wisata. Karakteristik sungai dengan air yang jernih dan bebatuan yang ada dengan lanskap hutan yang masih asri. Potensi atraksi kegiatan berbasis air dapat dilakukan di antaranya: berjalan susur sungai, tubing, maupun memancing. Selain itu, di desa sudah ada kolam pemancingan arus deras dan kolam renang dengan memanfaatkan air sungai. Fasilitas yang telah disediakan di sekitar sungai berupa lapangan untuk perkemahan, glamping ground, gazebo, pendopo, dan toilet umum.

Peraturan desa yang memaksa warga untuk tidak membuang sampah dan buang air (kecil/besar) di sungai patut diapresiasi. Aturan tersebut untuk menjaga kelestarian ekosistem sungai untuk keberlanjutan. Ancaman kerusakan kualitas lingkungan sungai dari aktivitas manusia dapat ditekan dengan adanya peraturan tersebut.

\section{Persawahan}

Persawahan yang ada di Desa Rindu Hati terletak di area resapan Sub-DAS Rindu Hati. Persawahan dengan latar belakang pegunungan merupakan daya tarik bagi wisatawan, khususnya yang berasal dari perkotaan dan daerah pesisir (Silitonga et al. 2013). Persawahan padi yang diusahakan selain menggunakan air dari sungai juga memanfaatkan jaringan irigasi. Persawahan masih menggunakan metode konvensional (lihat gambar 7). Dalam 2 tahun, persawahan di Desa Rindu Hati dapat melakukan panen hingga lima kali.

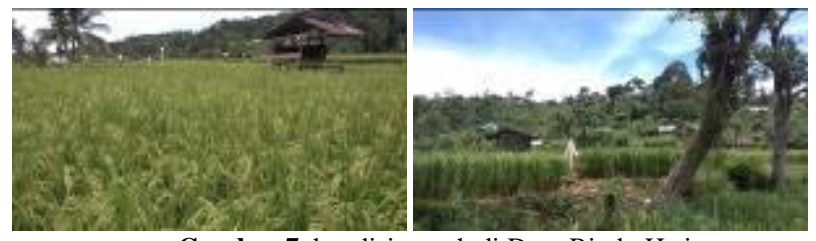

Gambar 7. kondisi sawah di Desa Rindu Hati (sumber: survei penyusun, 2020)
Kegiatan wisata yang dapat diusahakan dari bentang lingkungan pertanian sangat potensial. Selain pengembangan atraksi, pengembangan sarana akomodasi maupun amenitas pariwisata dapat dilakukan di bentang lingkungan sawah. Kegiatan susur sawah, memanen padi, menanam sayur mayur, dan menikmati keindahan alam merupakan beberapa atraksi yang dapat di lakukan di lahan pertanian.

\section{Hutan}

Bentang lingkungan alam hutan yang berada di Desa Rindu Hati masih sangat alami. Hutan tersebut masih termasuk bagian dari hutan adat dan sebagian masuk ke kawasan hutan lindung bukit daun dengan karakteristik tropis basah. Kondisi flora yang ada di hutan Desa Rindu Hati sangat beragam dan memungkinkan menjadi habitat alami bagi Amorphopalus maupun Rafflesia arnoldi (gambar 8).

Akses yang kurang terjangkau dengan jalan setapak memberikan sensasi petualangan dan pengalaman dalam berwisata. Potensi ekologi berupa batu tegak, padang rumput, dan bukit Endu. Dari atas bukit dapat melihat saujana bentang alam dan hutan yang masih asri.

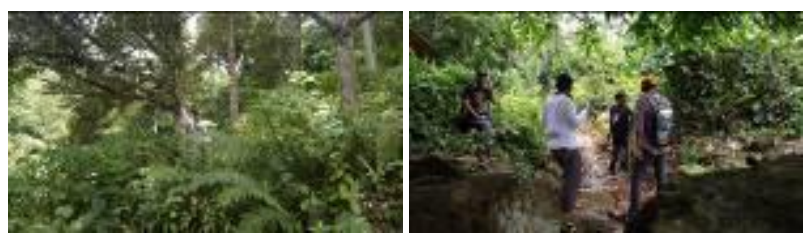

Gambar 8. kondisi hutan di Desa Rindu Hati (sumber: survei penyusun, 2020)

Kegiatan wisata yang dapat diusahakan dari lingkungan hutan ialah kegiatan hiking/ tracking, penelitian, bahkan kegiatan olah raga yakni, sepeda gunung, motor trail, hingga panjat tebing. Kondisi aksesibilitas yang masih jalan setapak dengan kontur yang dinamis memberikan tantangan tersendiri bagi wisatawan. Pengembangan atraksi wisata di lingkungan hutan selain untuk kegiatan rekreasi juga edukasi kepada wisatawan untuk mengetahui arti penting hutan bagi kehidupan.

\section{Identifikasi Potensi Objek Daya Tarik Wisata Alam}

\section{Objek daya tarik wisata yang berbentuk darat}

Daya tarik suatu kawasan merupakan hal utama yang menjadikan kawasan tersebut menarik minat wisatawan untuk berkunjung dan melakukan kegiatan wisata (Wulan et al. 2019). Basiya \& Rozak (2012) dalam Susana et al (2018) menyatakan bahwa daya tarik tempat wisata merupakan motivasi utama bagi pengunjung untuk melakukan kunjungan wisata. Keunikan dan sumberdaya alam yang menonjol merupakan salah satu kriteria daya tarik yang tidak bisa 
dipisahkan dari minat wisatawan untuk mengunjungi lokasi wisata (Rebong et al. 2017).

Desa wisata Rindu Hati memiliki potensi keunikan sumber daya alam berupa sumber air (sungai), air terjun, flora fauna, hingga budaya yang masih orisinal. Ditambah dengan bentukan alam yang dapat menjadi tenggara yang dapat diingat berupa air, batu, maupun flora.

Kegiatan yang dapat dilakukan beragam mulai dari kegiatan edukasi, tracking, mendaki, rafting, memancing, hingga berkemah. Lingkungan yang masih bersih, asri, jauh dari jalan poros utama, serta aman dari binatang pengganggu memberi nilai tambah terhadap ODTWA yang ada di Desa Rindu Hati.

Tabel 1. Penilaian Daya tarik/obyek wisata yang berbentuk darat

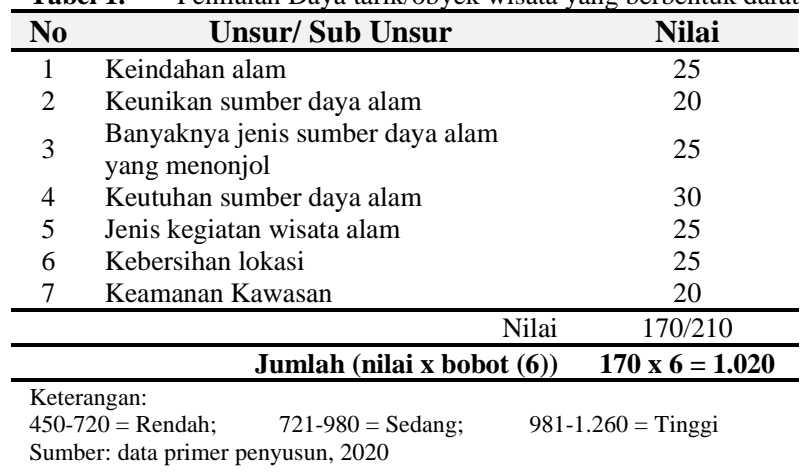

Berdasarkan penilaian yang dilakukan, skor untuk daya tarik/ objek wisata berbentuk darat masuk dalam klasifikasi tinggi atau potensial dengan jumlah 1.020 (tabel 1). Saujana/ bentang alam di desa memiliki serial vision yang berbeda-beda mulai dari pedesaan, persawahan, sungai, hingga hutan sehingga menghasilkan pandangan yang lepas di lingkungan objek. Hal ini merupakan potensi desa Rindu Hati untuk dapat dikembangkan menjadi desa berbasis wisata alam. Keadaan tersebut diperkuat dengan Masyarakat lokal relatif menerima dengan hadirnya orang dari luar desa untuk melakukan kegiatan wisata dan minimnya binatang pengganggu yang berada di sekitar kawasan wisata.

\section{Aksesibilitas}

Desa Rindu Hati berada di Kecamatan Taba Penanjung, Kabupaten Bengkulu tengah dengan $43 \mathrm{Km}$ ke arah timur dari Kota Bengkulu. Lokasi desa terletak di kecamatan terakhir sebelum kawasan hutan bukit barisan. Dari jalan poros Bengkulu - Kepahiang, desa ini berjarak 3 Kilometer dengan kondisi jalan dengan lebar 4 meter. Primadewi et al. (2020) mengatakan semakin tinggi nilai aksesibilitas akan membuat jumlah permintaan kunjungan wisata meningkat. Kemudahan aksesibilitas mempengaruhi kunjungan wisatawan dibandingkan dengan kawasan wisata yang memiliki tingkat aksesibilitas yang rendah (Budiarti et al. 2021).
Namun dalam ekowisata, wisatawan dengan minat khusus tidak membutuhkan fasilitas yang lengkap melainkan kejelasan jalan menuju objek wisata (Haris et al. 2017).

\begin{tabular}{|c|c|c|}
\hline No & Unsur/ Sub Unsur & Nilai \\
\hline 1 & $\begin{array}{l}\text { Kondisi dan jarak jalan darat dari ibu } \\
\text { kota provinsi }\end{array}$ & 60 \\
\hline 2 & $\begin{array}{l}\text { Waktu tempuh dari ibu kota Kota/ } \\
\text { Kabupaten }\end{array}$ & 30 \\
\hline \multirow[t]{3}{*}{3} & $\begin{array}{l}\text { Frekuensi kendaraan umum dari pusat } \\
\text { informasi ke obyek (buah/hari) }\end{array}$ & 10 \\
\hline & Nilai & $100 / 140$ \\
\hline & Jumlah (nilai $x$ bobot (5)) & $100 \times 5=500$ \\
\hline $\begin{array}{l}\text { Keter } \\
125-3 \\
\text { Sumb }\end{array}$ & $\begin{array}{l}=\text { Rendah; } \quad 318-508=\text { Sedang; } \\
\text { data primer penyusun, } 2020\end{array}$ & $=$ Tinggi \\
\hline
\end{tabular}

Berdasarkan hasil penilaian terhadap aksesibilitas (tabel 2), nilai yang dihasilkan masuk dalam klasifikasi kategori sedang dengan nilai 500. Kelebihan desa rindu Hati ialah jarak tempuh dan waktu tempuh menuju desa tidak terlalu jauh dari ibu kota. Perjalanan ke desa dapat ditempuh dalam kurun waktu 30 menit hingga satu jam dengan kendaraan bermotor. Untuk mencapai Desa Rindu Hati masih disarankan untuk menggunakan kendaraan pribadi maupun kendaraan sewa. Sangat jarang kendaraan umum yang dengan sengaja menuju desa wisata Rindu Hati. Di sisi lain, perlu ada peningkatan infrastruktur jalan untuk memudahkan akses pengunjung menuju desa Rindu Hati untuk menikmati keindahan alam di desa.

\section{Kondisi sekitar kawasan}

Hasil penilaian yang dilakukan terhadap kondisi sekitar kawasan menunjukkan klasifikasi sedang dengan skor 650 (tabel 3). Tata ruang objek wisata masih dalam tahap proses penyusunan sehingga diharapkan desa memiliki rencana pembangunan yang komprehensif baik pembangunan fisik maupun pembangunan manusianya. Pengamatan langsung yang dilakukan menunjukkan bahwasanya kondisi bentang alam yang dimiliki desa masih alami (lihat gambar 9) dan desa telah melakukan pembangunan serta pembenahan untuk menunjang kelengkapan kegiatan berwisata. Pemanfaatan material alami seperti kayu, bambu, dan sirap untuk membuat sarana dan prasarana wisata. Pembangunan sarana dan prasarana yang dilakukan selaras dengan alam pedesaan dan tidak merusak lingkungan.

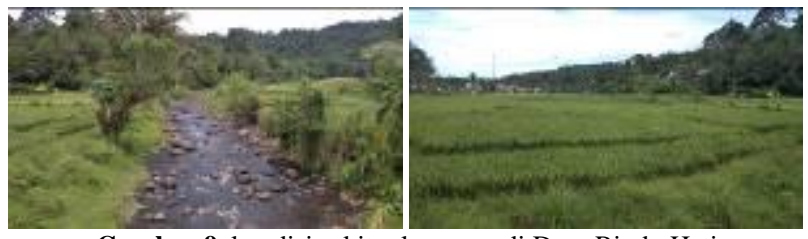

Gambar 9. kondisi sekitar kawasan di Desa Rindu Hati (sumber: survei penyusun, 2020) 
Masyarakat desa merupakan masyarakat agraris yang berprofesi sebagai petani. Penduduk memiliki sawah ataupun kebun yang berada tidak jauh dari permukiman. Hasil bumi dari perkebunan, pertanian maupun hutan menunjukkan wilayah desa memiliki tanah yang subur. Dalam dua tahun, petani dapat melakukan panen padi lima kali. Sebagai masyarakat agraris, mayoritas masyarakat desa sangat mendukung pengembangan Desa Rindu Hati menjadi Desa Wisata berbasis alam.

\begin{tabular}{|c|c|c|}
\hline No & Unsur/ Sub Unsur & Nilai \\
\hline 1 & Tata ruang wilayah obyek & 15 \\
\hline 2 & Mata pencaharian penduduk & 20 \\
\hline 3 & Ruang gerak pengunjung (ha) & 20 \\
\hline 4 & Pendidikan & 25 \\
\hline 5 & Tingkat kesuburan tanah & 20 \\
\hline \multirow[t]{3}{*}{6} & $\begin{array}{l}\text { Tanggapan masyarakat terhadap } \\
\text { Pengembangan obyek wisata alam }\end{array}$ & 30 \\
\hline & Nila & $130 / 180$ \\
\hline & Jumlah (nilai x bobot (5) & $130 \times 5=650$ \\
\hline $\begin{array}{l}\text { Kete } \\
350- \\
\text { Sum }\end{array}$ & $\begin{array}{l}\text { Igan: } \\
3=\text { Rendah; } \quad 534-717=\text { Sedang; } \\
\text { r: data primer penyusun, } 2020\end{array}$ & $0=$ Tinggi \\
\hline
\end{tabular}

\section{Daya dukung kawasan}

Daya dukung kawasan terhadap kegiatan wisata masuk dalam kategori tinggi, yang berarti masih jauh dari ambang batas kepadatan kunjungan (tabel 4). Kepadatan kunjungan tidak terlihat saat dilakukan observasi. Hanya beberapa orang yang melakukan aktivitas di air yang berasal dari desa sebelah di kabupaten Bengkulu tengah. Ruang yang dimanfaatkan untuk kegiatan berwisata berada di tepi air yang terletak di pinggir desa. Sehingga kegiatan wisata tidak mengganggu aktivitas masyarakat baik itu di permukiman maupun di ladang. Padahal, Potensi peningkatan jumlah pengunjung dapat memberikan keuntungan dari segi ekonomi (Susana et al. 2020).

Tabel 4. Penilaian Daya Dukung Kawasan

\begin{tabular}{|c|c|c|}
\hline No & Unsur/ Sub Unsur & Nilai \\
\hline 1 & Jumlah pengunjung (orang/hari/ha) & 30 \\
\hline 2 & Kepekaan tanah terhadap erosi & 25 \\
\hline 3 & Kemiringan lahan $(\%)$ & 15 \\
\hline 4 & Jenis kegiatan & 25 \\
\hline \multirow[t]{3}{*}{5} & Luas unit zona Pemanfaatan (ha) & 15 \\
\hline & Nilai & $110 / 150$ \\
\hline & Jumlah (nilai $x$ bobot (3)) & $110 \times 3=330$ \\
\hline $\begin{array}{l}\text { Kete } \\
75-2 \\
\text { Sum }\end{array}$ & $\begin{array}{l}\text { gan: } \\
=\text { Rendah; } \quad 201-325=\text { Sedang; } \\
\text { data primer penyusun, } 2020\end{array}$ & $0=$ Tinggi \\
\hline
\end{tabular}

Kondisi topografi desa yang relatif datar dan kemiringan lahan yang relatif dinamis sebagai pembatas daerah tangkapan air di Sub-DAS Rindu Hati. Kondisi desa yang diapit oleh perbukitan dengan vegetasi yang masih Virgin mampu menahan erosi di lereng perbukitan. Bentang alam desa yang berada di lembah tersebut menjadi area yang dapat dikembangkan untuk kegiatan wisata berbasis alam. Dengan kondisi desa yang terletak di ceruk/ lembah dengan kondisi yang relatif datar, kegiatan berwisata ataupun rekreasi alam dapat dilaksanakan dengan aman.

\section{Pengelolaan dan pelayanan}

Pengelolaan dan pelayanan wisatawan perlu ditingkatkan. Keberhasilan pengelolaan tergantung dukungan dan penghargaan terhadap kawasan yang dilindungi oleh masyarakat sekitarnya (Purwanto et al. 2014). Berdasarkan hasil penilaian (tabel 5), pengelolaan dan pelayanan masih dalam kategori sedang yang berarti perlu adanya peningkatan pengelolaan dan pelayanan. Peningkatan pengelolaan dapat ditingkatkan dilakukan dengan adanya POKDARWIS (kelompok Sadar Wisata) di DESWITA (desa wisata) menjadi ujung tombak kegiatan wisata di desa.

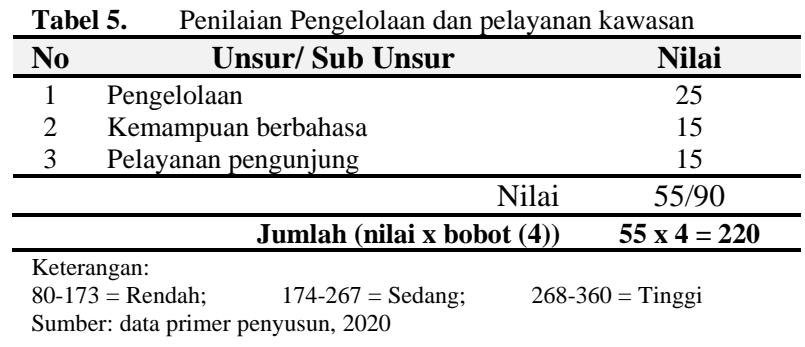

Berdasarkan unsur penilaian (tabel 5), nilai-nilai keramahtamahan yang merupakan bagian dari pelayanan dapat ditingkatkan melalui pelatihan komunikasi dan bahasa. Diharapkan pemandu desa memiliki kemampuan berkomunikasi yang baik dengan menggunakan bahasa komunikasi yang umum baik dalam maupun mancanegara. Penggunaan bahasa yang baik dapat memperjelas maksud dari komunikasi antara wisatawan dan tuan rumah.

\section{Akomodasi}

Akomodasi merupakan salah satu komponen dasar pembentuk pariwisata. Akomodasi merupakan faktor yang diperlukan bagi pengunjung dari tempat yang cukup jauh untuk tinggal lebih lama di kawasan wisata, namun kurang dimanfaatkan bagi pengunjung yang berasal dari kota sekitar (Susana et al. 2020).

Hasil penilaian akomodasi masuk dalam kategori rendah dengan skor 30 (tabel 6). Kondisi tersebut dikarenakan Akomodasi yang terdapat di sekitar Desa Rindu Hati masih sangat terbatas. Hal ini dikarenakan letak desa yang berbatasan langsung dengan Taman nasional, batas Kabupaten, dan jauh dari Ibu kota. Akomodasi yang dimaksud adalah hotel maupun penginapan. Letak penginapan maupun hotel terdekat berada di pinggir ibu kota provinsi Bengkulu. Sedangkan jarak Desa Rindu Hati ialah 43 Km dari Kota Bengkulu. 


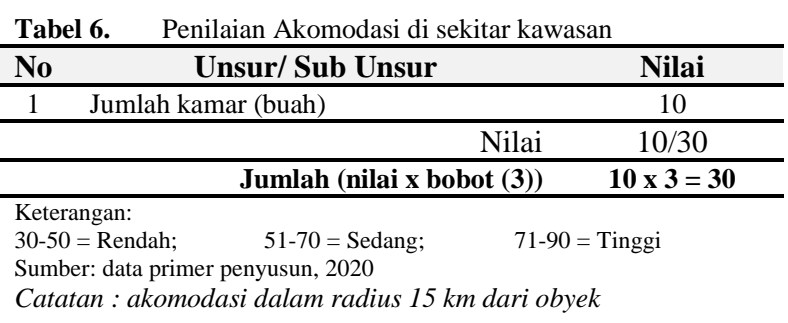

Keterbatasan jenis akomodasi ini memberikan peluang bahwasanya desa dapat mengembangkan jenis akomodasi yang unik dan berbeda. Pembuatan homestay di beberapa rumah penduduk, glamping ground, camping ground bisa menjadi alternatif akomodasi. Menurut Chusmeru \& Noegroho (2010) home stay dengan konsep tinggal bersama dengan para penduduk agar wisatawan bisa langsung mempelajari kehidupan masyarakat desa ketika menginap di sana.

\section{Sarana prasarana penunjang}

Sarana dan prasarana pariwisata merupakan fasilitas yang memungkinkan proses kegiatan pariwisata berjalan dengan lancar sehingga dapat memudahkan setiap orang yang terlibat dalam kegiatan berwisata (Purwanto et al. 2014). Sarana dan prasarana penunjang pariwisata yang berada di Desa Rindu Hati sudah memadai untuk langkah awal eksistensi desa wisata. Hasil penilaian terhadap sarana dan prasarana penunjang tergolong tinggi dengan jumlah 165 (tabel 7).

Sarana penunjang kegiatan wisata yang ada untuk saat ini berupa MCK, sarana wisata tirta, dan akomodasi berupa glamping ground. Sarana rumah makan/minum, kios Cinderamata, sarana angkutan umum, akomodasi perlu ditingkatkan untuk pengembangan ODTWA. Jika memungkinkan, diadakan ATM atau atm keliling untuk memudahkan wisatawan mengambil uang di kawasan wisata.

Tabel 7. Penilaian Sarana prasarana Penunjang di sekitar kawasan

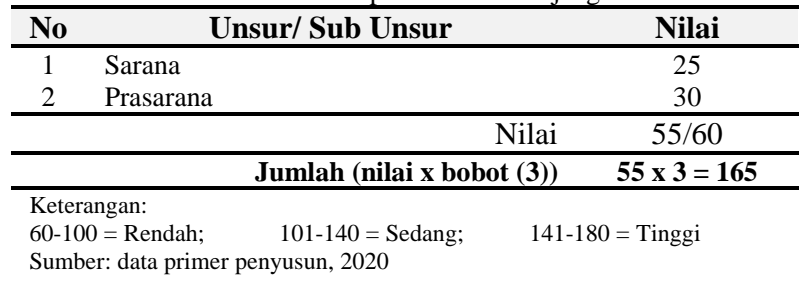

Prasarana yang ada di desa rindu hati berupa jalan, jembatan, jaringan listrik, area parkir, dan jaringan air minum. Jalan yang ada berupa rabat beton dan aspal dengan kondisi yang kurang baik di beberapa titik. Jembatan di dekat lapangan menjadi ikon kawasan dan tidak dapat dilalui kendaraan roda 4. Jaringan listrik sudah masuk hingga ke tiap gazebo glamping ground. Sedangkan air bersih menggunakan sumber mata air dari bukit dan hutan (gambar 10).

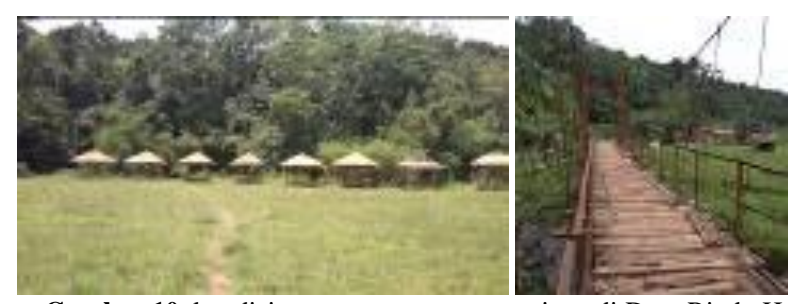

Gambar 10. kondisi sarana prasarana penunjang di Desa Rindu Hati (sumber: survei penyusun, 2020)

Perlu adanya penambahan lahan/ area parkir untuk menampung kendaraan wisatawan yang ingin berkunjung. Selain itu perlu adanya sistem drainase untuk mengurangi limbah dari kegiatan wisata langsung terbuang ke sungai. Jaringan komunikasi perlu ditingkatkan dengan menambahkan menara provider untuk kelancaran akses komunikasi pengunjung selama berada di area wisata.

\section{Ketersediaan air bersih}

Berdasarkan data penilaian (tabel 8), ketersediaan air bersih di desa Rindu Hati sangat tinggi. Air bersih sangat melimpah dan ada sepanjang tahun di Desa Rindu Hati. Sumber air berasal dari pegunungan, hutan maupun sungai yang menjadi atraksi utama di desa. Sumber air dari sungai yang mengalir di selatan permukiman dapat menjadi potensi atraksi, baik itu atraksi berbasis alam atau atraksi yang sengaja dibuat untuk mendatangkan wisatawan.

Pemanfaatan air untuk kegiatan wisata selain untuk atraksi juga digunakan untuk fasilitas penunjang wisata. Semisal kamar mandi, wudhu, ataupun untuk fasilitas rumah makan \& minum. Air di sungai Rindu Hati dapat langsung dikonsumsi, namun akan lebih baik apabila mendapatkan perlakuan sederhana sebelum dikonsumsi.

Tabel 8. Penilaian ketersediaan air bersih di sekitar kawasan

\begin{tabular}{|c|c|c|}
\hline No & Unsur/ Sub Unsur & Nilai \\
\hline 1 & Volume & 30 \\
\hline 2 & Kepekaan tanah terhadap erosi & 30 \\
\hline 3 & $\begin{array}{l}\text { Jarak lokasi air bersih terhadap lokasi } \\
\text { obyek }\end{array}$ & 30 \\
\hline 4 & Jenis kegiatan & 25 \\
\hline \multirow[t]{3}{*}{5} & Dapat tidaknya air dialirkan ke obyek & 30 \\
\hline & Nilai & $145 / 150$ \\
\hline & Jumlah (nilai $x$ bobot $(6)$ ) & $145 \times 6=870$ \\
\hline $\begin{array}{l}\text { Kete } \\
180 \\
\text { Sum }\end{array}$ & $\begin{array}{l}\text { = Rendah; } \quad 421-660=\text { Sedang; } \\
\text { data primer penyusun, } 2020\end{array}$ & $=$ Tinggi \\
\hline
\end{tabular}

\section{Keamanan}

Keamanan berkaitan dengan kenyamanan pengunjung dan kelestarian kawasan (Purwanto et al. 2014). Berdasarkan penilaian yang dilakukan (tabel 9), tingkat keamanan Desa Rindu Hati cukup tinggi. Selain karena lokasi desa yang tidak berada di jalan poros Bengkulu - Kepahiang, kondisi masyarakat desa yang 
ramah dan religius yang dapat menerima orang lain (wisatawan) dengan baik.

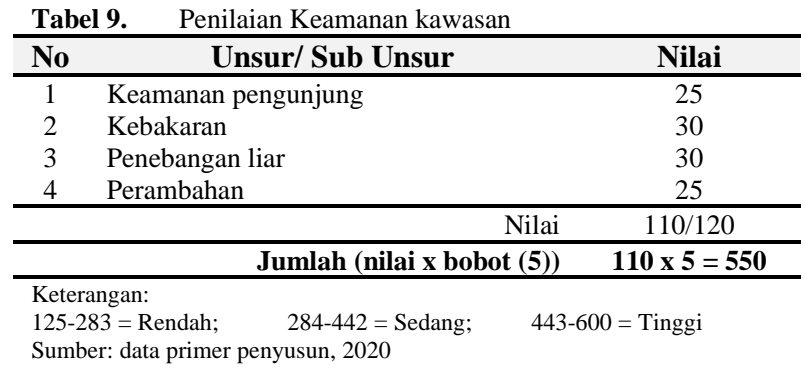

Kondisi lingkungan sosial cenderung kondusif. Peraturan desa dan adat setempat masih berlaku. Sehingga minim terjadinya gangguan keamanan dan ketertiban di masyarakat. Beberapa hewan dengan sengaja dibiarkan (tidak diletakkan dalam kandang) namun hal tersebut bukan menjadi ancaman saat melakukan wisata.

Kebakaran dan kebakaran hutan jarang terdengar di desa rindu hati. Adapun jika terjadi dikarenakan faktor alam. Kegiatan penebangan dan mengambil hasil hutan berupa kayu hanya untuk kepentingan pribadi dan tidak diperjual belikan dengan cara penebangan ilegal di desa. kegiatan perambahan yang dilakukan warga desa hanya untuk membuat ladang menetap dan tidak di kawasan hutan konservasi. Masyarakat membuat ladang dan sawah di bagian barat desa Rindu Hati. Hasil dari kegiatan ladang berupa sayur, cabai, terung, buahbuahan, dan kopi.

\section{Potensi Pasar}

Hasil penilaian menunjukkan bahwa potensi pasar sangat rendah dengan skor 310 (tabel 10). Hal ini dikarenakan jumlah warga di provinsi bengkulu yang kurang dari 5 juta jiwa dan kepadatan penduduk kurang dari 200 penduduk $/ \mathrm{km}^{2}$. Selain hal tersebut, hal yang membuat potensi di provinsi bengkulu lemah dikarenakan berwisata dilakukan jika ada kesempatan, tingkat kejenuhan rutinitas harian, dan perilaku berwisata yang penasaran dengan adanya tempat baru yang cukup terjangkau dari ibu kota.

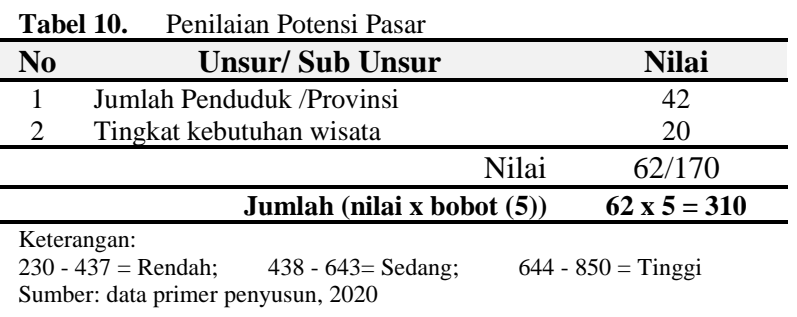

Potensi pasar wisata Desa Rindu Hati akan lebih baik melirik ke pasar luar Provinsi Bengkulu daripada di dalam Provinsi Bengkulu. Selain kepadatan dan jumlah penduduk yang sedikit, karakteristik masyarakat sekitar yang menjadi pengunjung atau wisatawan yang cenderung memiliki kesamaan bentang alam maupun aktivitas sehari hari dengan desa rindu hati.

Ekspansi pasar dengan melakukan promosi digital akan sangat efektif dilakukan untuk saat ini. Pemanfaatan sosial media sebagai sarana promosi memiliki potensi besar untuk mendatangkan pengunjung. Reservasi dapat dilakukan dengan mudah sebelum ke lokasi tujuan.

\section{Pemasaran}

Pemasaran yang telah dilakukan Desa Rindu Hati berupa promosi melalui media sosial elektronik dan pembebasan tarif untuk memasuki area wisata. Wisatawan hanya dikenakan biaya kebersihan untuk berkunjung ke area wisata di luar atraksi wisata. Pemasaran yang dilakukan cukup masif, namun perlu penambahan jumlah dan jenis media pemasaran. Saat ini, promosi yang dilakukan sudah cukup baik dengan adanya tarif wisata, namun belum adanya diversifikasi produk wisata dan pelayanan paket wisata terpadu. Wisatawan belum dapat menikmati kegiatan wisata di desa Rindu Hati secara utuh dengan beberapa alternatif atraksi wisata maupun paket wisata yang ditawarkan (table 11).

\begin{tabular}{|c|c|c|}
\hline No & Unsur/ Sub Unsur & Nilai \\
\hline \multirow[t]{3}{*}{1} & Bauran pemasaran & 15 \\
\hline & Nilai & $15 / 30$ \\
\hline & Jumlah (nilai $x$ bobot (4)) & $15 \times 4=60$ \\
\hline $\begin{array}{l}\text { Kete } \\
20-5 \\
\text { Suml }\end{array}$ & $\begin{array}{l}\text { ngan: } \\
=\text { Rendah; } \quad 54-87=\text { Sedang; } \\
\text { r: data primer penyusun, } 2020\end{array}$ & $=$ Tinggi \\
\hline
\end{tabular}

\section{Pangsa Pasar}

Hasil penilaian menunjukkan bahwa pangsa pasar sangat tinggi dengan skor 360 (tabel 12). Pangsa pasar yang paling potensial adalah wisatawan yang berasal dari luar kabupaten dan luar Provinsi Bengkulu. Sebagai langkah awal, karakteristik wisatawan yang dapat dirangkul adalah segmen mass tourism dengan rentang usia 25 - 34 tahun. Kelompok wisatawan pada usia ini cenderung memiliki jiwa petualangan yang tinggi dan secara finansial cukup mapan. Selain itu, segmen dengan mata pencaharian sebagai pegawai yang akan mengunjungi saat weekend menjadi entry point promosi masal melalui media sosial yang dimiliki wisatawan. Langkah awal ini merupakan upaya untuk mendatangkan segmen wisatawan minat khusus yang menjadi target utama kunjungan yang akan datang sebagai dampak dari promosi generasi milenial melalui sosial media. 
Tabel 12. Penilaian Pangsa Pasar

\begin{tabular}{|c|c|c|}
\hline No & Unsur/ Sub Unsur & Nilai \\
\hline 1 & Asal pengunjung & 25 \\
\hline 2 & Usia & 15 \\
\hline 3 & Tingkat pendidikan & 25 \\
\hline \multirow[t]{3}{*}{4} & Mata pencaharian & 25 \\
\hline & Nilai & $90 / 120$ \\
\hline & Jumlah (nilai x bobot (4)) & $90 \times 4=360$ \\
\hline $\begin{array}{l}\text { Kete } \\
80-2 \\
\text { Suml }\end{array}$ & $\begin{array}{l}\text { Jan: } \\
=\text { Rendah; } \quad 214-347=\text { Sedang; } \\
\text { data primer penyusun, } 2020\end{array}$ & $=$ Tinggi \\
\hline
\end{tabular}

\section{Rekapitulasi Penilaian ODTWA Desa Rindu Hati}

Nilai ODTWA berikut ini merupakan penjumlahan berdasarkan kriteria yang telah dijelaskan sebelumnya. Total persentase indeks nilai berdasarkan penjumlahan ialah $68,79 \%$. Nilai tersebut mengindikasikan bahwasanya desa rindu hati memiliki potensi yang cukup besar untuk dikembangkan namun perlu peningkatan untuk beberapa aspek yang telah disebutkan sebelumnya. Untuk lebih jelas memahami rekapitulasi penilaian ODTWA Desa Rindu Hati, dapat dilihat dalam tabel 13 berikut ini.

Tabel 13. Rekapitulasi Penilaian ODTWA Desa Rindu Hati

\begin{tabular}{|c|c|c|c|c|c|}
\hline No & Kriteria & $\begin{array}{l}\text { Nilai } \\
\text { mak- } \\
\text { simal }\end{array}$ & $\begin{array}{c}\text { Nilai } \\
\text { potensi }\end{array}$ & $\begin{array}{l}\text { Indeks } \\
\text { nilai } \\
\text { potensi }\end{array}$ & $\begin{array}{c}\text { Klasifi- } \\
\text { kasi } \\
\text { potensi } \\
\text { ODTWA }\end{array}$ \\
\hline 1 & $\begin{array}{l}\text { Daya tarik/obyek } \\
\text { wisata yang } \\
\text { berbentuk darat }\end{array}$ & 1260 & 1.020 & $80,95 \%$ & Tinggi \\
\hline 2 & Aksesibilitas & 700 & 500 & $71,43 \%$ & Sedang \\
\hline 3 & $\begin{array}{l}\text { Kondisi sekitar } \\
\text { kawasan }\end{array}$ & 900 & 650 & $72,22 \%$ & Sedang \\
\hline 4 & $\begin{array}{l}\text { Daya dukung } \\
\text { kawasan }\end{array}$ & 450 & 330 & $73,33 \%$ & Tinggi \\
\hline 5 & $\begin{array}{l}\text { Pengelolaan dan } \\
\text { pelayanan }\end{array}$ & 360 & 220 & $61,11 \%$ & Sedang \\
\hline 6 & Akomodasi & 90 & 30 & $33,33 \%$ & Rendah \\
\hline 7 & $\begin{array}{l}\text { Sarana prasarana } \\
\text { penunjang }\end{array}$ & 180 & 165 & $91,67 \%$ & Tinggi \\
\hline 8 & $\begin{array}{l}\text { Ketersediaan air } \\
\text { bersih }\end{array}$ & 900 & 870 & $96,67 \%$ & Tinggi \\
\hline 9 & Keamanan & 600 & 500 & $83,33 \%$ & Tinggi \\
\hline 10 & Potensi Pasar & 850 & 310 & $36,47 \%$ & Rendah \\
\hline 11 & Pemasaran & 120 & 60 & $50,00 \%$ & Sedang \\
\hline \multirow[t]{2}{*}{12} & Pangsa pasar & 480 & 360 & $75,00 \%$ & Tinggi \\
\hline & jumlah & 6.890 & 5.065 & $69,49 \%$ & Sedang \\
\hline
\end{tabular}

Keterangan:

$1.775-3.480=$ Rendah; $3.481-5.185=$ Sedang $; 5.186-6.890=$ Tinggi

Sumber: data primer penyusun, 2020

Untuk meningkatkan potensi ODTWA yang terdapat di Desa Rindu Hati, perlu peningkatan dalam aspek pengelolaan dan pelayanan serta pemasaran. Dalam aspek pengelolaan dan pelayanan dapat ditingkatkan sisi manajemen pengelolaan, peningkatan komunikasi dengan cara peningkatan kecakapan berbahasa, dan peningkatan kemampuan pelayanan dan keramahtamahan (hospitality). Dalam aspek pemasaran, perlu menetapkan paket wisata yang akan ditawarkan kepada wisatawan, besaran tarif untuk kegiatan wisata, diversifikasi atraksi wisata, serta adanya pusat informasi bagi wisatawan. Wisatawan dapat menerima informasi yang baik dan benar tentang desa wisata Rindu Hati sehingga mereka akan mempersiapkan dengan baik agar dapat berwisata dengan nyaman.

Aspek akomodasi dan potensi pasar memerlukan perhatian khusus untuk segera ditingkatkan. Jenis dan jumlah akomodasi yang ada di sekitar desa wisata Rindu Hati perlu dilakukan registrasi \& pencatatan baik dari sisi kapasitas maupun jenis akomodasi. Sehingga, wisatawan dapat memilih jenis akomodasi yang sesuai dengan keinginan mereka. Rendahnya potensi pasar lokal (Provinsi Bengkulu) menjadi tantangan untuk ekspansi promosi desa wisata Rindu Hati ke luar Provinsi Bengkulu. Adanya media elektronik akan sangat membantu untuk kegiatan promosi untuk memperbesar peluang pasar dan mendapatkan target pasar yang sesuai dengan karakteristik yang diinginkan.

\section{KESIMPULAN}

Identifikasi potensi objek daya tarik wisata alam di hulu DAS Bengkulu Desa Rindu Hati Kecamatan Taba Penanjung Bengkulu Tengah memberikan temuan:

1. Bentang alam yang menjadi potensi daya tarik wisata berbasis alam di Desa Wisata Rindu Hati antara lain: sungai, pertanian, kehutanan, dan desa itu sendiri. Atraksi/daya tarik wisata tersebut harus memiliki nilai edukasi dan konservasi lingkungan alam.

2. Desa Rindu Hati cukup potensial untuk dijadikan desa wisata berbasis alam. Hal tersebut berdasarkan penilaian dengan menggunakan ADO-ODTWA yang menunjukkan skor sedang, yakni 69,79\%. Perlu pembenahan dalam beberapa aspek untuk meningkatkan kualitas kunjungan wisatawan.

3. Pengembangan desa rindu hati menjadi desa wisata berbasis alam dapat dilakukan dengan segera melakukan pembenahan dalam aspek akomodasi, potensi pasar, pengelolaan dan pelayanan, serta pemasaran. Pembenahan tersebut juga diiringi dengan peningkatan kualitas aksesibilitas serta diversifikasi produk dan fasilitas wisata.

Hasil temuan penelitian identifikasi potensi objek daya tarik wisata alam di hulu DAS Bengkulu Desa Rindu Hati Kecamatan Taba Penanjung Bengkulu Tengah memberikan wawasan dan pemahaman mengenai potensi bentang alam di desa yang berada di hulu daerah aliran sungai dapat dikembangkan menjadi objek daya tarik wisata berbasis alam. Walaupun perlu pembenahan dan peningkatan untuk beberapa aspek demi terwujudnya desa wisata berbasis alam. Selain itu, penulis mengharapkan penelitian ini dapat 
dikembangkan lebih lanjut untuk mengoptimalkan Desa Rindu Hati sebagai desa wisata berbasis alam.

\section{UCAPAN TERIMA KASIH}

Penelitian ini dapat dilaksanakan dengan lancar berkat bantuan dari berbagai pihak. Terima kasih kepada:

1. Universitas Bengkulu selaku pemberi dana penelitian pembinaan bagi dosen muda.

2. Pimpinan LPPM Universitas Bengkulu, yang telah memberikan kepercayaan untuk menjadikan penelitian ini menjadi embrio desa wisata dan menjadikan Desa Rindu Hati sebagai desa binaan Universitas Bengkulu.

3. Perangkat Desa dan warga Desa Rindu yang telah menerima kami menjadi bagian desa dalam melakukan penelitian di Desa. serta

4. Pihak-pihak lain yang terlibat dalam penelitian ini yang tidak dapat disebutkan satu per satu.

\section{DAFTAR PUSTAKA}

Adiati, M. P. \& Basalamah, A. (2014) Kondisi Pariwisata Berkelanjutan di Bidang Sosial Budaya Berdasar Pengalaman dan Harapan Pengunjung di Pantai Tanjung Papuma, Jember. BINUS Business Review, 5 (1), 80 - 90.

Budiarti, W., Siradjuddin, I., \& Idham, A. (2021) Arahan Pengembangan Desa Wisata Di Desa Pincara Kabupaten Luwu Utara. Jurnal Ilmiah Membangun Desa dan Pertanian (JIMDP), 6 (1), $14-24$.

Chusmeru, \& Noegroho, A. (2010). Potensi Ketenger Sebagai Desa Wisata di Kecamatan Batu Raden, Kabupaten Banyumas. Jurnal Analisis Pariwisata, 10(1), 16-23.

Cory Wulan, C., Albayudi, \& Lidiarti, T. (2019) Analisis Potensi Ekowisata di Kawasan Rawa Bento Kabupaten Kerinci. Jurnal Silva Tropika, 3 (1), 95 - 107.

Direktorat Produk Pariwisata. (2003) Pedoman Penilaian Daya Tarik Wisata. Direktorat Jenderal Pengembangan Destinasi Wisata. Departemen Kebudayaan dan Pariwisata Republik Indonesia.

Haris, M., Soekmadi, R., \& Arifin, H. S. (2017) Potensi Daya Tarik Ekowisata Suaka Margasatwa Bukit Batu Kabupaten Bengkalis Provinsi Riau. Jurnal Penelitian Sosial dan Ekonomi Kehutanan, 14 (1), $39-56$.

Iskandarrudin, Arifin, S., \& Utomo, B. (2018) Kajian Pengembangan Ekowisata Salang Pangeran di Kawasan Taman Nasional Gunung Leuser. Jurnal Serambi Engineering, 3 (1), 197 - 208.

Kurniasari, E., Rustiadi, E., \& Tonny, F. (2013) Strategi Pengembangan Ekowisata Melalui Peningkatan Partisipasi Masyarakat, Studi Kasus Komunitas
Kelurahan Kalimulya Kota Depok. Jurnal Manajemen Pembangunan Daerah. 5 (2), 32 47.

Nugroho, M.N.D. (2015) Manajemen Pengunjung di Taman Pintar Yogyakarta. Tesis. Program Pasca Sarjana Fakultas Teknik, Universitas Gadjah Mada, Yogyakarta.

Perlindungan Hutan dan Konservasi Alam (PHKA) (2003) Pedoman Analisis Daerah Operasi Obyek dan Daya Tarik Wisata Alam (ADO-ODTWA) Direktorat Jenderal Perlindungan Hutan dan Konservasi Alam. Bogor.

Primadewi, E., Rispantyo, \& Wardiningsih, S. S. (2020). Analisis Faktor Promosi, Aksesibilitas dan Bukti Fisik terhadap Keputusan Berkunjung Wisatawan (Studi pada Destinasi Wisata Gunung Beruk Desa Karangpatihan Kecamatan Balong Kabupaten Ponorogo). Jurnal Manajemen Sumber Daya Manusia, 14 (Edisi Khusus Maret), $13-23$.

Pujaastawa, I.B.G. \& Ariana, I. N. (2015) Pedoman Identifikasi Potensi Daya Tarik Wisata. Konsorsium Riset Pariwisata, Universitas Udayana, Denpasar.

Purwanto, S., Syaufina. L., \& Gunawan, A. (2014) Kajian Potensi dan Daya Dukung Taman Wisata Alam Bukit Kelam untuk Strategi Pengembangan Ekowisata. Jurnal Pengelolaan Sumberdaya Alam dan Lingkungan. 4 (2), 119 - 125.

Rebong, V. E., Soelistyono, R., \& Kusumawardani, N.D. (2017) Studi Pengembangan Potensi Wisata Alam di Pesisir Pantai Ena Gera Menuju Desa Wisata. Konservasi Sumberdaya Hutan Jurnal Ilmu-ilmu Kehutanan, 1 (4), 30 - 50.

Silitonga, F., Latifah, S., \& Afifuddin, Y. (2013) Analisis Potensi Ekowisata Di Desa Sosor Dolok, Kecamatan Harian, Kabupaten Samosir (Analysis of Ecotourism Potential in Sosor Dolok Village, Harian Sub District, Samosir Regency)." Peronema Forestry Science Journal, 2 (1), 82 87.

Soemarwoto, O. (1989) Ekologi Lingkungan Hidup dan Pembangunan. Djambatan, Jakarta.

Sunaryo, B. (2013) Kebijakan Pembangunan Destinasi Pariwisata : Konsep dan Aplikasinya di Indonesia. Penerbit Gava Media, Yogyakarta.

Susana, M., Kusmana, C., \& Arifin, H. S. (2020) Potensi Daya Tarik Ekowisata Mangrove di Desa Karangsong, Kabupaten Indramayu. Jurnal Penelitian Sosial dan Ekonomi Kehutanan, 17 (3), $193-208$.

Susanti, A. D. (2015). Pola Partisipasi Warga dalam Pengembangan Desa Wisata Umbul Sidomukti Kabupaten Semarang. MODUL, 15(1), 47-56. https://doi.org/10.14710/mdl.15.1.2015.47-56 
Susanti, A. D., \& Mandaka, M. (2019) Evaluation on Sumber Seneng Natural Park, Rembang as Tourism Object Using ADO-ODTWA Analysis. MODUL, 19 (1), 25 - 32.

Yoeti, O. A. 1985. Pengantar Ilmu Pariwisata. Angkasa, Bandung. 